\title{
www.czasopisma.pan.pl

\section{Influence of Soaking Parameters on the Segregation and Corrosion Resistance of GJS-X350NiMnCu7-3-2 Ductile Iron}

\author{
D. Medyński ${ }^{\text {a,* }}$, A. Janus ${ }^{\text {b }}$, M. Stachowicz ${ }^{\text {b }}$ \\ ${ }^{a}$ Witelon State University of Applied Science in Legnica, Department of Technical and Economic Sciences, \\ Sejmowa 5A, 59-220 Legnica, Poland \\ ${ }^{\mathrm{b}}$ Wroclaw University of Technology, Mechanical Faculty, Department of Foundry Engineering, Plastics and Automation, \\ Smoluchowskiego 25, 50-372 Wrocław, Poland \\ * Corresponding author. E-mail address: d.medynski.pwsz@interia.pl
}

Received 14.03.2017; accepted in revised from 22.05.2017

\begin{abstract}
In this paper, the effect of changes the parameters of heat treatment on the structure and the degree of elements segregation was determined, in the context of corrosion resistance of ductile iron $\mathrm{Ni}-\mathrm{Mn}-\mathrm{Cu}$, containing $7.2 \% \mathrm{Ni}, 2.6 \% \mathrm{Mn}$ and $2.4 \% \mathrm{Cu}$. In the condition after casting, castings of austenitic matrix and 160HBW hardness were obtained. The achieved castings were soaked at 450, 550 and $650^{\circ} \mathrm{C}$ for 4,8 and 12 hours, then cooled down at the ambient air. In most cases, the heat treatment resulted in a change in the castings matrix, had the consequence of increasing their hardness in comparison to raw castings. Increasing the temperature and prolonging soaking time resulted in increasing the degree of transformation of austenite, while reducing the degree of elements segregation. This led to the formation of slightly bigger number of pitting due to corrosion, but not so deep and more evenly distributed in comparison to raw castings. Wherein the results of corrosion tests show that heat treatment of castings did not significantly change their corrosion resistance in comparison to raw castings, in contrast to the significant increase in mechanical properties.
\end{abstract}

Keywords: Heat treatment, Austenitic ductile iron, Transformation of austenite, Segregation of elements, Corrosion resistance

\section{Introduction}

Obtaining an austenitic casting requires introduction to an alloy sufficiently large, total amount of nickel, manganese and copper [1-4]. Austenitic operation of these elements is mostly to inhibit the diffusion of carbon in austenite. This leads to prolonging incubation time and/or lowering the temperature of pearlitic, bainitic and martensitic transformation [5-11]. Nonequilibrium solidification conditions and relatively high speed of castings cooling lead to oversaturation austenite with carbon. This can lead to its strong segregation. The degree of the carbon segregation also depends on the average carbon concentration and the degree of segregation of the remaining elements dissolved in the matrix [12].

Soaking of raw castings, may lead, at the temperature activating diffusion, to a partial transformation of austenite. It especially applies for alloys for which the value of nickel equivalent (EkwNi), calculated according to the following dependence, is $\mathrm{EkwNi}_{\mathrm{N}} \approx 16 \%$ [13]:

$\mathrm{EkWNi}_{\mathrm{Ni}}=0.32 \cdot \mathrm{C}+0.13 \cdot \mathrm{Si}+\mathrm{Ni}+2.48 \cdot \mathrm{Mn}+0.53 \cdot \mathrm{Cu}[\%]$ 
It means that castings working in elevated temperature can lead to spontaneous change in its structure. This negative phenomenon, from the austenite thermodynamic durability point of view, can be used for the controlled change in the structure, favorable from the point of view of castings mechanical properties [13].

A typical representative of this material is GJS$\mathrm{X} 350 \mathrm{NiMnCu}$ 7-3-2 cast iron. It is possible to increase the mechanical properties and abrasive wear resistance, due to partial transformation of austenite into acicular phase, morphologically similar to martensite or ferrite acicular in bainite or ausferrite. It can be achieved by soaking combined with cooling in the atmospheric air. The appropriate choice of heat treatment parameters (temperature, soaking time) makes it possible to control a method and a degree of austenite transformation [13]. It allows for a predetermined proportion obtaining between strength and fragility of the casting, as in the case of ADI cast iron [14].

It is therefore legitimate to determine whether and to what extent, changing the soaking parameters, causing a change in the structure of the castings matrix, will affect the destruction of their surface due to corrosion. It should be assumed that the decisive factor will be a change in the degree of elements segregations.

\section{Purpose, scope and methodology}

The aim of the study was to determine the effect of heat treatment of spheroidal cast iron GJS-X350NiMnCu7-3-2 to change in the degree of elements segregation in the matrix, in the context of corrosion resistance.

The study was conducted for spheroidal cast iron containing $3.4 \% \mathrm{C} ; 2.3 \% \mathrm{Si} ; 7.2 \% \mathrm{Ni} ; 2.6 \% \mathrm{Mn} ; 2.4 \% \mathrm{Cu} ; 0.11 \% \mathrm{Mg}$, $0.15 \% \mathrm{P}$ and $0.04 \% \mathrm{~S}$. Castings for research type $\mathrm{Y}$ (according to PN-76/H-83124) were obtained by casting the alloy at about $1420^{\circ} \mathrm{C}$ in molds made of a wet bentonite mass. After cooling and taking out the castings, test samples were taken. Due to the possibility of macrosegregation appearance, samples were taken from the same areas of castings, about $10 \mathrm{~mm}$ from the surface. The heat treatment was based on soaking the samples at 450, 550 and $650^{\circ} \mathrm{C}$ for 4,8 and 12 hours, and then cooling in the ambient air.

Analysis of the chemical composition of the casting was performed by means of the spectral method with the use of glow discharge analyser and by means of energy-dispersive X-ray spectroscopy and wavelength-dispersive X-ray Spectroscopy with the use of a FEI Quanta scanning electron microscope.

Microscopic observations were performed with the use of an optical microscope ECLIPSE MA200 Nikon, scanning electron microscope Hitachi TM 3000 and FEI Quanta. In addition, by means of SEM it was possible to determine the indicators defining the topography of the samples surface after corrosive tests.

Gravimetric and potentiodynamic methods were used for the corrosive tests. In both cases the corrosive environment was a $3 \%$ aqueous $\mathrm{NaCl}$ solution at ambient temperature. In gravimetric research, in order to increase the aggressiveness of the environment, aerated solution of atmospheric air was applied [15].

The results of the gravimetric research are shown in the form of changes in weight of material per time unit on an area unit of the $\mathrm{V}_{\mathrm{C}}$ sample, and after conversion, according to the equation taking into account material density [15-17], as linear rate of corrosion in time $V_{P}[\mathrm{~mm} /$ year $]$ :

$\mathrm{V}_{\mathrm{P}}=0.0365 \cdot \mathrm{V}_{\mathrm{C}} / \mathrm{d}$

where:

$\mathrm{V}_{\mathrm{C}}-$ mass loss of specimen in time per unit area $\left[\mathrm{mg} /\left(\mathrm{dm}^{2} \cdot \mathrm{day}\right)\right]$, $\mathrm{d}-$ metallic material density $\left[\mathrm{g} / \mathrm{cm}^{3}\right]$.

Potentiodynamic measurements were performed in a conventional three-electrode system fully automated. The reference electrode was a calomel electrode. As a counter electrode, a platinum electrode was used. Corrosion resistance was assessed on the basis of corrosion current density ( $i_{\text {kor }}$ ), polarization resistance $\left(R_{P}\right)$ and the potentials: cathode - anode passage (EK-A), and stationary (E') $[3,4,18]$.

\section{Results and discussion}

\subsection{Microstructure and hardness}

Heat treatment, in most cases, caused partial austenite. Its method and the degree strictly depended on the soaking parameters. Increasing the temperature and prolonging the soaking time resulted in an increase of the degree of austenite transformation, and the increase in castings hardness in comparison to raw castings (160HBW). Wherein, at lower temperatures martensite was created (Fig. 1a). Soaking at $550^{\circ} \mathrm{C}$ led to changes in morphology, and it started to resemble acicular ferrite which appear in bainite (Fig. 1b). Soaking in the highest temperature resulted in perlite appearance (Fig. 1c). The test results are summarized in table1.
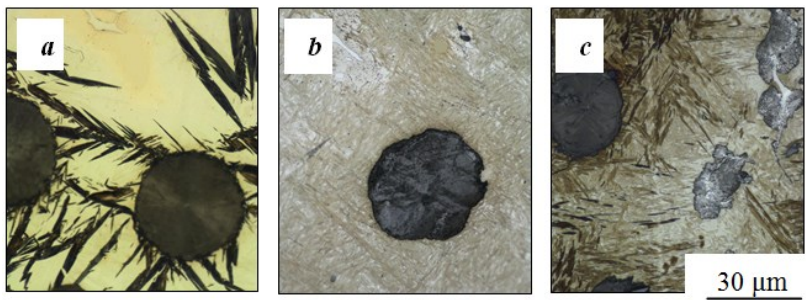

Fig. 1. The microstructure of castings soaked at: a) $450^{\circ} \mathrm{C}$ for 8 $\mathrm{h}$ (graphite ball, single martensite needles, austenite),

$550^{\circ} \mathrm{C}$ for $8 \mathrm{~h}$ (graphite ball, acicular ferrite, retained austenite), c) $650^{\circ} \mathrm{C}$ for $8 \mathrm{~h}$ (graphite ball, dispersion perlite, acicular ferrite, retained austenite, cementite), then cooled on the air. Etched MilFe 
Table 1.

Microstructure and HBW hardness of castings depending on temperature and time of soaking

\begin{tabular}{cccccc}
\multirow{2}{*}{$\begin{array}{c}\text { Soaking } \\
\text { time } \\
{[\mathbf{h}]}\end{array}$} & \multicolumn{4}{c}{ Soaking temperature $\left.{ }^{\circ} \mathbf{C}\right]$} \\
\cline { 2 - 6 } & $\begin{array}{c}\mathbf{4 5 0} \\
\mathbf{F e}_{\gamma}-\mathbf{F e}_{\boldsymbol{\alpha}}-\mathbf{P} \\
{[\%-\%-\%]}\end{array}$ & $\mathbf{H B W}$ & $\begin{array}{c}\mathbf{F e}_{\gamma}-\mathbf{F e}_{\boldsymbol{\alpha}},-\mathbf{P} \\
{[\%-\%-\%]}\end{array}$ & $\mathbf{H B W}$ & $\begin{array}{c}\mathbf{F e}_{\gamma}-\mathbf{F e}_{\boldsymbol{\alpha}},-\mathbf{P} \\
{\left[\%-\%_{-}-\%\right]}\end{array}$ \\
\hline $\mathbf{4}$ & $100-0-0$ & 159 & $64-36-0$ & 349 & $45-50-5$ \\
\hline $\mathbf{8}$ & $96-4-0$ & 210 & $8-87-5$ & 452 & $6-84-10$ \\
\hline $\mathbf{1 2}$ & $94-6-0$ & 250 & $6-85-9$ & 442 & $6-78-16$ \\
\hline
\end{tabular}

$\mathrm{Fe}_{\gamma}$ - austenite; $\mathrm{Fe}_{\alpha^{\prime}}-$ martensite and acicular ferrite; $\mathrm{P}$ - perlite

\subsection{Microsegregation}

In all examined castings there was a segregation of elements in the eutectic colonies. The degree of segregation depend on the type of an element and the distance from a measuring point to graphite. The measurement results of elements microsegregation for raw castings are shown in Table 2, and for the soaked castings in Table 3.

On the basis of the measurement results presented in Table 2 and 3 , coefficients of eutectic segregation $\mathrm{K}_{\mathrm{A}}$ were calculated as the ratio of elements presence in the boundary area of eutectic colony to its concentration in the vicinity of graphite. The results are shown in Table 4

Table 2.

$\underline{\text { Segregation of elements in the eutectic colonies for raw castings }}$

\begin{tabular}{ccccc}
\hline \multirow{2}{*}{ Raw castings } & \multicolumn{4}{c}{ Average concentration of element [wt.\%] } \\
\cline { 2 - 6 } & $\mathbf{C}$ & $\mathbf{S i}$ & $\mathbf{N i}$ & $\mathbf{M n}$ \\
\hline concentration in a casting & 3.40 & 2.30 & 7.20 & 2.50 \\
\hline concentration in austenite & 0.48 & 2.58 & 7.92 & 2.53 \\
\hline near the boundaries of eutectic colonies & 0.50 & 2.47 & 7.32 & 2.64 \\
\hline near the graphite & 0.45 & 2.69 & 8.52 & 2.42 \\
\hline
\end{tabular}

Table 3.

Segregation of elements in the eutectic colonies for soaked castings

\begin{tabular}{|c|c|c|c|c|c|c|c|}
\hline \multirow{2}{*}{\multicolumn{2}{|c|}{ Soaking parameters }} & \multirow{2}{*}{ Place of measurement } & \multicolumn{5}{|c|}{ Average concentration of element [wt.\%] } \\
\hline & & & $\mathbf{C}$ & Si & $\mathbf{N i}$ & Mn & $\mathbf{C u}$ \\
\hline \multirow{6}{*}{$450^{\circ} \mathrm{C}$} & $4 h$ & \multirow{3}{*}{$\begin{array}{l}\text { near the boundaries of } \\
\text { eutectic colonies }\end{array}$} & 0.50 & 2.47 & 7.32 & 2.64 & 2.46 \\
\hline & $8 \mathbf{h}$ & & 0.50 & 2.49 & 7.33 & 2.63 & 2.49 \\
\hline & 12h & & 0.49 & 2.50 & 7.35 & 2,63 & 2.50 \\
\hline & $4 h$ & \multirow{3}{*}{ near the graphite } & 0.45 & 2.69 & 8.52 & 2,42 & 2.58 \\
\hline & $8 \mathrm{~h}$ & & 0.45 & 2.67 & 8.51 & 2.43 & 2.55 \\
\hline & $12 \mathrm{~h}$ & & 0.46 & 2.66 & 8.49 & 2.43 & 2.54 \\
\hline \multirow{6}{*}{$550^{\circ} \mathrm{C}$} & $4 h$ & \multirow{3}{*}{$\begin{array}{l}\text { near the boundaries of } \\
\text { eutectic colonies }\end{array}$} & 0.50 & 2.50 & 7.35 & 2.62 & 2.50 \\
\hline & $8 \mathrm{~h}$ & & 0.49 & 2.52 & 7.37 & 2.61 & 2.51 \\
\hline & $12 \mathrm{~h}$ & & 0.48 & 2.51 & 7.39 & 2.59 & 2.51 \\
\hline & $4 h$ & \multirow{3}{*}{ near the graphite } & 0.45 & 2.66 & 8.49 & 2.44 & 2.54 \\
\hline & $8 \mathbf{h}$ & & 0.46 & 2.64 & 8.46 & 2.45 & 2.53 \\
\hline & $12 \mathrm{~h}$ & & 0.47 & 2.63 & 8.44 & 2.46 & 2.53 \\
\hline \multirow{6}{*}{$650^{\circ} \mathrm{C}$} & $4 h$ & \multirow{3}{*}{$\begin{array}{l}\text { near the boundaries of } \\
\text { eutectic colonies }\end{array}$} & 0.50 & 2.52 & 7.37 & 2.61 & 2.51 \\
\hline & $8 \mathrm{~h}$ & & 0.49 & 2.53 & 7.39 & 2.59 & 2.51 \\
\hline & $12 \mathrm{~h}$ & & 0.48 & 2.55 & 7.47 & 2.58 & 2.52 \\
\hline & $4 h$ & \multirow{3}{*}{ near the graphite } & 0.45 & 2.64 & 8.46 & 2.45 & 2.53 \\
\hline & $8 \mathbf{h}$ & & 0.46 & 2.63 & 8.44 & 2.47 & 2.53 \\
\hline & $12 \mathrm{~h}$ & & 0.48 & 2.61 & 8.35 & 2.48 & 2.52 \\
\hline
\end{tabular}


Table 4.

The values of segregation's coefficients in the eutectic colonies $K_{A}$ for the individual elements in the raw castings and the soaked ones.

Segregation coefficient of elements in the eutectic colonies $\left(K_{A}\right)$

for the castings

Elements

\begin{tabular}{|c|c|c|c|c|c|c|c|c|c|}
\hline \multirow{3}{*}{ raw } & \multicolumn{9}{|c|}{ soaked } \\
\hline & \multicolumn{3}{|c|}{$450^{\circ} \mathrm{C}$} & \multicolumn{3}{|c|}{$550^{\circ} \mathrm{C}$} & \multicolumn{3}{|c|}{$650^{\circ} \mathrm{C}$} \\
\hline & $4 h$ & $8 h$ & $12 \mathrm{~h}$ & $4 h$ & $8 h$ & $12 \mathrm{~h}$ & $4 h$ & $8 h$ & $12 \mathrm{~h}$ \\
\hline 1,11 & 1.11 & 1.11 & 1.10 & 1.11 & 1.10 & 1.02 & 1.11 & 1.10 & 1.01 \\
\hline 1,10 & 1.09 & 1.08 & 1.08 & 1.07 & 1.07 & 1.05 & 1.07 & 1.05 & 1.04 \\
\hline 0,86 & 0.86 & 0.86 & 0.87 & 0.87 & 0.88 & 0.89 & 0.86 & 0.88 & 0.90 \\
\hline 0,92 & 0.92 & 0.93 & 0.94 & 0.94 & 0.95 & 0.95 & 0.93 & 0.96 & 0.98 \\
\hline 0,94 & 0.95 & 0.98 & 0.98 & 0.98 & 0.99 & 0.99 & 0.99 & 0.99 & 0.99 \\
\hline
\end{tabular}

Carbon and manganese have tendencies for normal microsegregation. In the vicinity of graphite, concentration of these elements is lower than near the boundaries of eutectic colonies. The average value of the coefficient $K_{A}$ is greater than one.

Nickel has tendency for inverse microsegregation. In the vicinity of graphite, concentration of nickel was visibly higher than near the boundaries of eutectic colonies. Silicon and copper have the same pattern but with lower intensity. Average values of microsegregation's coefficient for silicon and copper are similar and close to one $(0.92 \div 0.99)$, indicating a slight segregation of these elements.

Heat treatment resulted in reduction of the degree of segregation of all the elements. The degree of segregation was decreasing with increasing the temperature and prolonging duration time of soaking. Coefficient $K_{A}$ approaching one shows that.

\subsection{Corrosive research}

Gravimetric and potentiodynamic measurements were carried out for 168 hours. Samples were weighed and subjected to polarization after $24,48,72,96$ and 168 hours of exposure to $3 \%$ $\mathrm{NaCl}$ solution. It was found that the effect of heat treatment on the corrosion rate was insignificant. This is confirmed by the measurement results shown in Table 5 .

A clear effect on the corrosion rate had exposure time of the samples in a corrosive environment. Rate of samples corrosion after 24 hours amounted to $1.00 \div 1.18 \mathrm{~mm} /$ year. After 168 hours exposure the samples showed reduced corrosion rate by about $25 \%$. A preferred feature of the tested materials was systematic decrease in the rate of corrosion after more than 48 hours of keeping them in a solution of $\mathrm{NaCl}$. The results are shown in Table 5.

Table 5.

The average corrosion rate $\mathrm{V}_{\mathrm{P}}[\mathrm{mm} / \mathrm{year}]$ at different times after exposition of samples in a $3 \% \mathrm{NaCl}$ solution for a raw casting and soaked ones

\section{Rate of corrosion VP [mm/year]}

for the castings

\begin{tabular}{|c|c|c|c|c|c|c|c|c|c|c|}
\hline \multirow{4}{*}{$\begin{array}{l}\text { Exposure time of } \\
\text { samples in the corrosive } \\
\text { solution }[\mathrm{h}]\end{array}$} & \\
\hline & \multirow{3}{*}{ raw } & \multicolumn{9}{|c|}{ soaked } \\
\hline & & \multicolumn{3}{|c|}{$450 C^{0}$} & \multicolumn{3}{|c|}{$550^{\circ} \mathrm{C}$} & \multicolumn{3}{|c|}{$650^{\circ} \mathrm{C}$} \\
\hline & & $4 h$ & $8 h$ & $12 \mathrm{~h}$ & $4 h$ & $8 h$ & $12 \mathrm{~h}$ & $4 h$ & $8 h$ & $12 \mathrm{~h}$ \\
\hline 24 & 1.00 & 1.00 & 1.05 & 1.09 & 1.05 & 1.08 & 1.15 & 1.11 & 1.08 & 1.18 \\
\hline 48 & 1.09 & 1.10 & 1.11 & 1.12 & 1.13 & 1.11 & 1.20 & 1.12 & 1.12 & 1.20 \\
\hline 72 & 0.96 & 0.96 & 0.97 & 0.97 & 1.02 & 1.06 & 1.10 & 1.00 & 1.05 & 1.15 \\
\hline 96 & 0.89 & 0.90 & 0.89 & 0.91 & 0.95 & 0.90 & 0.93 & 0.90 & 1.00 & 1.05 \\
\hline 168 & 0.80 & 0.81 & 0.80 & 0.84 & 0.84 & 0.79 & 0.86 & 0.89 & 0.89 & 0.86 \\
\hline
\end{tabular}


The polarization of samples was started from the potential of $850 \mathrm{mV}$ NEC in the anode direction at a rate of $1 \mathrm{mV} / \mathrm{s}$. The results are presented in Table 6 .

Because the gravimetric research showed no significant impact of the samples annealing time on the rate of corrosion thereof, in Table 6, there are shown only the results of the polarizing research for the casting soaked for 8 hours at 450, 550 and $650^{\circ} \mathrm{C}$, for the shortest $(1 \mathrm{~h})$ and the longest $(168 \mathrm{~h})$, the samples exposure time in the corrosive solution.

Table 6.

Electrochemical parameters (cathode-anode potential EK-A, stationary potential E', corrosion current density $i_{\text {corr, }}$, polarization resistance $\mathrm{R}_{\mathrm{P}}$ ) after 1 hour and 168-hours exposure in a corrosive solution for raw and soaked for 8 hours castings

\begin{tabular}{|c|c|c|c|c|c|c|c|c|}
\hline \multirow{2}{*}{ Castings } & \multicolumn{2}{|c|}{$\begin{array}{l}\mathbf{E}_{\mathrm{K}-\mathrm{A}} \\
{[\mathrm{mV}]}\end{array}$} & \multicolumn{2}{|c|}{$\begin{array}{c}\mathbf{E}^{\prime} \\
{[\mathrm{mV}]}\end{array}$} & \multicolumn{2}{|c|}{$\begin{array}{c}\mathbf{i}_{\text {corr }} \\
{\left[\mu \mathbf{A} / \mathbf{c m}^{2}\right]}\end{array}$} & \multicolumn{2}{|c|}{$\begin{array}{c}R_{\mathbf{p}} \\
{\left[\mathrm{k} \Omega \cdot \mathbf{c m}^{2}\right]}\end{array}$} \\
\hline & $1 \mathrm{~h}$ & $168 \mathrm{~h}$ & $1 \mathrm{~h}$ & $168 \mathrm{~h}$ & $1 \mathrm{~h}$ & $168 \mathrm{~h}$ & $1 \mathrm{~h}$ & $168 \mathrm{~h}$ \\
\hline & & & & & 56,4 & & 1.0 & \\
\hline $450 C^{\circ}$ & -578 & -670 & -544 & -521 & 55,6 & 12 & 1.1 & 0.1 \\
\hline & -586 & -688 & -574 & -542 & 32,9 & 107 & 1.3 & 0.3 \\
\hline $650^{\circ} \mathrm{C}$ & -593 & -696 & -578 & -554 & 24,5 & 118 & 1.4 & 0.2 \\
\hline
\end{tabular}

Small differences of potential value of cathode-anode EK-A transition indicate homogeneity of electrode processes occurring on a metal surface. This is due to the same chemical composition of all the tested castings, despite the diversity of their structure.

Changing the parameters of heat treatment resulted in a slight change in stationary potential E'. Maximum potential value, both after shorter $\left(E^{\prime}=-539 \mathrm{mV}\right)$ and after longer exposure time of samples $\left(E^{\prime}=-512 \mathrm{mV}\right)$ were found for the raw castings material. The lowest $E^{\prime}$ value was measured for the iron casting soaked at the highest temperature (after a short time of exposure it reached $578 \mathrm{mV}$, and after a long time $-554 \mathrm{mV}$ ). Prolonged exposure of the samples resulted in a slight increase in the E' value for all the tested samples, which is a positive phenomenon from the surface protection the point of view.

Effect of heat treatment on the corrosion current density icorr and polarization resistance $R_{P}$ was insignificant $i_{\text {corr }}$ and $R_{P}$ values showed an inverse relationship. Increasing the soaking temperature resulted in the reduction of $i_{\text {corr }}$ and increasing $\mathrm{R}_{\mathrm{P}}$ values, which is a positive phenomenon from the corrosion resistance point of view. Out of the tested samples the smallest

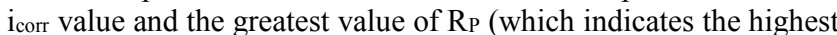
corrosion resistance), showed iron casting soaked at $550^{\circ} \mathrm{C}$ for 8 hours. Prolongation samples exposure time from 1 hour to 168 hours had an adverse effect on the corrosion resistance of all the tested samples. There was an increase in $\mathrm{i}_{\text {corr }}$ and reduction in $\mathrm{R}_{\mathrm{P}}$ value between the shorter and longer exposure time of the samples.

\subsection{SEM research}

Both in the case of raw castings and the soaked ones, the nature of corrosion damage was similar. Surface damage both raw casting and the soaked one at $550^{\circ} \mathrm{C}$ for 8 hours, caused by potentiodynamic research, are shown in Figure 2. Losses in material were located mainly near the boundaries of eutectic colonies (Fig. 2a2, 2b2). In case of soaked castings corrosive destruction could also be seen inside the eutectic colony, near the acicular ferrite $\left(2 b_{2}\right)$.
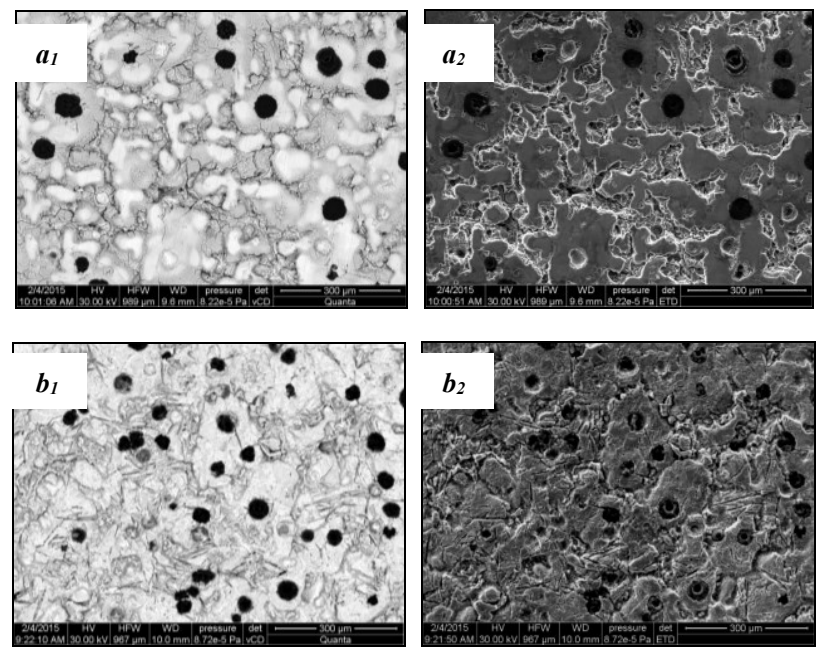

Fig. 2. SEM images of the castings surface, after potentiodynamic measurements, performed with the use of different techniques: a) raw casting - BSE technique $\left(a_{1}\right)$, SE technique $\left(a_{2}\right)$; b) soaked casting at $550^{\circ} \mathrm{C}$ for 8 hours - BSE technique $\left(b_{1}\right)$, SE technique (b2)

Using SEM imaging indicators defining the topography of the samples surface resulting from corrosion damage were determined. Individual indicators were determined for measurement sections, which amounted $31.95 \mu \mathrm{m}$. Defined average values: the height of the highest peak of the profile $\left(R_{\text {pAVR }}\right)$, the depth of the lowest recess of the profile $\left(R_{V A V R}\right)$, the height of the roughness between the highest peak, and the lowest recess $\left(R_{\mathrm{ZAVR}}=\mathrm{R}_{\mathrm{PAVR}}+\mathrm{R}_{\mathrm{VAVR}}\right)$, mean arithmetic deviation of the profile from the mean line, measured along the measurement section ( $\mathrm{R}_{\mathrm{a} A \mathrm{R}}$ ), and a mean square root deviation of the profile from the mean line along the measurement section $\left(\mathrm{R}_{\mathrm{qAVR}}\right)$. The results are summarized in Table 7.

Table 7.

Indicators determining the mean surface roughness of raw castings and the soaked ones

\begin{tabular}{cccccc}
\hline \multirow{2}{*}{ Castings } & \multicolumn{5}{c}{ Indicator of surface roughness $[\boldsymbol{\mu m}]$} \\
\cline { 2 - 6 } & $\mathbf{R}_{\mathbf{p A V R}}$ & $\mathbf{R}_{\text {VAVR }}$ & $\mathbf{R}_{\text {zAVR }}$ & $\mathbf{R}_{\text {aAVR }}$ & $\mathbf{R}_{\mathbf{q A V R}}$ \\
\hline raw & 9.15 & 27.82 & 36.97 & 5.02 & 6.60 \\
\hline $\mathbf{4 5 0}^{\circ} \mathbf{C} / \mathbf{8 h}$ & 11.20 & 20.13 & 31.33 & 2.79 & 4.14 \\
\hline $\mathbf{5 5 0}^{\circ} \mathbf{C} / \mathbf{8 h}$ & 7.44 & 11.80 & 19.24 & 0.89 & 1.54 \\
\hline $\mathbf{6 5 0}^{\circ} \mathbf{C} / \mathbf{8 h}$ & 7.14 & 18.49 & 25.63 & 0.95 & 1.62 \\
\hline
\end{tabular}




\section{Conclusions}

Heat treatment of austenitic iron GJS-X350NiMnCu7-3-2, in most cases, caused a change in the structure of the castings matrix.

Increasing the temperature and prolonging the soaking time caused a change in the way and increased the degree of austenite transformation. A method for transformation was changing from non-diffusive transformation, at lower temperatures (austenite $\rightarrow$ martnesite), by partly by diffusional (austenite $\rightarrow$ acicular ferrite) until the transformation of the diffusion character at maximum temperatures (austenite $\rightarrow$ perlite).

Both in raw castings and the soaked castings there was a normal segregation of carbon, manganese and silicon and negative segregation of nickel and copper in the eutectic colonies. Castings soaking connected with cooling in the ambient air reduced the degree of separation of all the elements.

Parameters determining the topography of samples surface after the corrosive tests, indicate that the reduction of segregation degree due to soaking, resulted in a slightly greater number of pits of smaller depth and more even layout in comparison to the raw casting. It should be noted as a positive phenomenon from the surface protection against corrosion point of view of. Wherein, the results of potentiodynamic and gravimetric research show that the heat treatment did not significantly change the corrosion resistance in comparison to the raw casting, in contrast to substantial increase in strength, hardness [13] and, as it can be assumed, wear resistance of the castings.

\section{References}

[1] Samsonowicz, Z., Janus, A. (1992). Medium-nickel austenitic cast iron type $\mathrm{Ni}-\mathrm{Mn}-\mathrm{Cu}$. Report of Institute of Machine Engineering and Automation of Wroctaw University of Technology. SPR 29 (in Polish).

[2] Janus, A. \& Stachowicz, M. (2014). Thermodynamic stability of austenitic Ni-Mn-Cu cast iron. Metalurgija. 53(3), 353-356.

[3] Medyński, D. \& Janus, A. (2015). Effect of nickel equivalent on structure and corrosion resistance of nodular cast iron Ni$\mathrm{Mn}-\mathrm{Cu}$. Archives of Foundry Engineering. 15(1), 69-74.

[4] Medyński, D. \& Janus, A. (2016). Effect of austenite transformation on abrasive wear and corrosion resistance of spheroidal Ni-Mn-Cu cast iron. Archives of Foundry Engineering. 16(3), 63-66.

[5] Nayyar, V., Kaminski, J., Kinnander, A. \& Nyborg, L. (2012). An experimental investigation of machinability of graphitic cast iron grades. Flakes, compacted and spheroidal graphite iron in continuous machining operations. Procedia CIRP. No. 1, 488-493.

[6] Hellal, F., Lacaze, J. \& Hazotte, A. (1999). Carbon transfer during austenite decomposition into ferrite and graphite in a spheroidal-graphite caste iron. Canadian Journal of Physics. 77(9), 677-684.

[7] Ahmadabadi, M.N. \& Shamloo, R. (2001). Control of austenitic transformations in ductile iron aided by calculation of Fe-C-Si-X phase boundaries. Journal of Phase Equilibria. 22(3), 1994-1998.

[8] Lacaze, J., Boudot, A., Gerval, V., Oquab, D. \& Santos, H. (1997) The role of manganese and copper in the eutectoid transformation of spheroidal graphite cast iron. Metallurgical and Materials Transactions A. 28(10), 2015-2025.

[9] Chang L.C. (2004). Microstructures and reaction kinetics of bainite transformation in Si-rich steels. Material Science and Engineering A. Vol. 368, 175-182.

[10] Gumienny, G. (2010). Bainitic-martensitic nodular cast iron with carbides. Archives of Foundry Engineering. 10(2), 6368.

[11] Pietrowski, S. \& Gumienny, G. (2006). Crystallization of nodular cast iron with additions of $\mathrm{Mo}, \mathrm{Cr}, \mathrm{Cu}$ and $\mathrm{Ni}$. Archives of Foundry. 6(22), 406-413 (in Polish).

[12] Oddy, A.S., McDill, J.M, Karlson, (1996). Microstructural predictions including arbitrary thermal histories, reaustenization and carbon segregation effects. Canadian Metallurgicall Quartterly. 35(3), 275-283.

[13] Medyński, D. \& Janus, A. (2016). Effect of heat-treatment parameters of cast iron GJS-X350NiMnCu7-3-2 on its structure and mechanical properties. $57^{\text {th }}$ International Scientific Conference: Solidification and Crystallization of Metals 2016, 19-21 September 2016 Cedzyna, Kielce, Poland: Archives of Foundry Engineering. 17(1), 121-126.

[14] Guzik, E. (2006). Selected issues forming structure and properties ausferritic cast iron. Archives of Foundry. 6(21), 33-42 (in Polish).

[15] Hryniewicz, T., Rokosz, K. (2010). Theoretical basis and practical aspects of corrosion. Koszalin: Editorial Office of Koszalin University of Technology (in Polish).

[16] Bala, H. (2002). Corrosion of materials - theory and practice. Czestochowa: Editorial Office of Process Engineering. Materials and Applied Physics of Czestochowa University of Technology (in Polish).

[17] Rączka, J.S., Tabor, A. \& Kowalski, A. (2000). Resistance of austenitic-bainitic nodular cast iron to corrosive action of sulphuric, nitric and hydrochloric acids. Solidification of Metals and Alloys. 2(44), 527-535 (in Polish).

[18] Cheng-Hsun, H., Ming-Li, C. (2010). Corrosion behavior of nickel alloyed and austempered ductile iron in 3,5\% sodium chloride. Corrosion Science. 52, 2945-2949. 